\title{
THE EFFECTS OF PENICILLIN ADMINISTRATION ON MENSTRUAL AND OTHER SEXUAL CYCLE FUNCTIONS
}

\author{
BY \\ A. E. W. McLACHLAN and DONALD D. BROWN \\ Venereal Diseases Medical Officers, City and County of Bristol
}

Since penicillin became available for the treatment of bacterial infections, the nontoxicity of the drug has been the subject of universal emphasis. Nevertheless, a number of toxic sequelæ, chiefly of minor importance, have been reported. These were more frequent in the early days of penicillin therapy, have gradually become less common, and were probably correctly ascribed, in the majority of cases, to the impurities unavoidably present in the commercially processed drug. The standard of purity attained by the time that penicillin became available for the treatment of gonorrhœe and syphilis in the civilian clinics of this country has made untoward drug-sequelæ extremely rare, in our experience, with the exception of those related to the menstrual function.

Early in our series of cases, alterations in the normal menstrual cycle of non-pregnant patients were observed, notably the onset of premature menstrual periods, lengthened periods, increased loss, and premenstrual or trual dysmenorrhœea, and, in the case of ant women, the occurrence of uterine os in relation to penicillin administration. rst these were presumed to be due to cal pathological conditions present or to rxheimer-like reaction.

.e frequency of menstrual sequelæ, howseemed to indicate that the drug or some rity was the cause. That this was indeed the aase was proved by the occurrence of si Ir phenomena in uninfected control cases, i healthy volunteer, the other two being mild cases of trichomonatous vaginitis whose treatment had been completed. These 3 patients were particularly chosen for their previous constancy in menstrual cycle, loss, and dysmenorrhoa. The results of the administration of 150,000 Oxford units of penicillin, given in 5 doses each of 30,000 units at 3-hourly intervals, are shown graphically in Figs. 1, 2, 3. In one of the patients menstruation occurred 7 days before the expected date: in the other two the periods were delayed by 7 and 10 days respectively. The duration of menstrual flow was increased by 2 to 3 days in all 3 patients. Loss was increased in all instances, and clots were also increased in the 2 cases in which they normally occurred. Premenstrual dysmenorrhœa was increased in one, abolished in one, and instituted in the third. Menstrual dysmenorrhœa, severe in one patient, occurred for the first time in all 3 patients and persisted throughout the period. In these cases the subsequent periods were normal in all respects. This experiment indicated that menstrual irregularities could be instituted by the penicillin available, and it was decided to investigate the subject further.

Examination of the literature has revealed few observations on the menstrual sequelæ of penicillin administration. Leavitt (1945) states : "The effect of penicillin in inducing premature menstruation or in prolonging menstruation already started has been the subject of comment by several of the doctors contributing to the Bulletin of the Rapid Treatment Centres." Unfortunately we have not been able to obtain access to this publication. In his personal series of cases, Leavitt found that 8 out of 21 pregnant patients treated with penicillin manifested symptoms of uterine activity-uterine cramps, bleeding, 


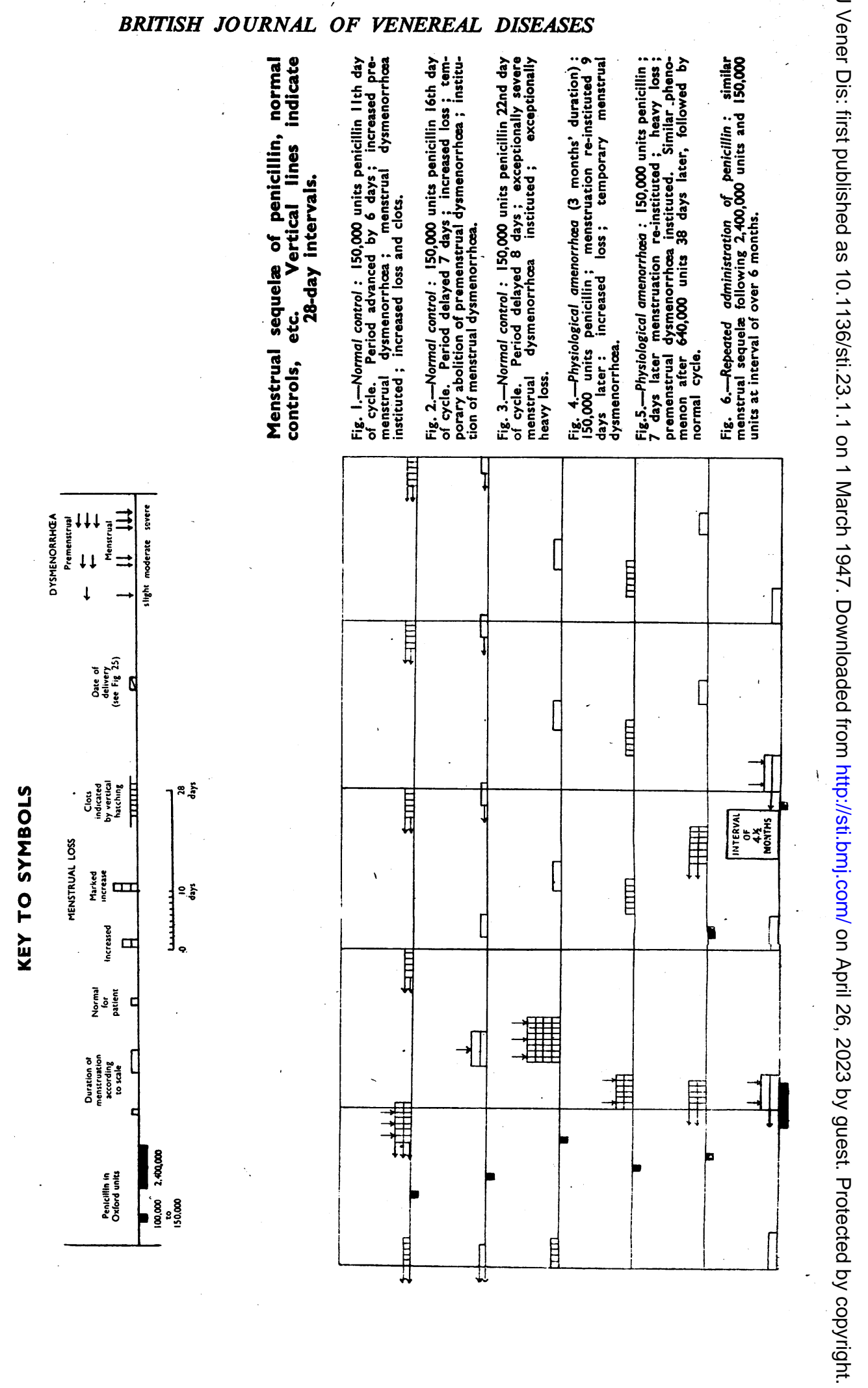


or both. Of these 8 patients, 2 evacuated the contents of the uterus. He considered that the action of the penicillin on the uterus might be due to some impurity, as 7 of these 8 cases had been treated with the same batch of the drug. Lentz and others (1944) noted 2 cases of threatened abortion following penicillin treatment for syphilis in pregnant women. Mascall (1945) stated that almost all his patients complained of premenstrual pain or uterine pain; menorrhagia was a marked symptom, and if the period was nearly due its onset was expedited. In 2 cases of early pregnancy there had been abortion. He believed that these side-effects were due, not to the penicillin, but to some associated impurities. Walker (1945) had also noted similar menstrual phenomena.

Speiser and others (1946) did not observe any menstrual abnormality following penicillin therapy attributable to the drug. In only 1 instance in 100 cases of early syphilis treated with penicillin was there any alteration from the usual cycle. He suggested that some associated pathological process may have accounted for the intermenstrual bleeding noted by other workers. (This, in view of our recent observations with pure penicillin, may be a reflex of the purity of the drug used by Speiser and others.)

\section{Personal Observations}

The immediate and later sexual-cycle sideeffects of penicillin administration have been studied in an unselected series of 216 nonpregnant women observed, except where otherwise indicated, for a minimum of 4 posttherapeutic menstrual cycles, in 32 pregnant women treated at varying stages of gestation, and in 16 women whose treatment commenced during the puerperium. Sodium and calcium salts of varying batches and of different manufacture have been employed in aqueous solution, or in beeswax-arachis-oil or beeswaxethyl-oleate emulsion. There has been insufficient evidence to indicate that any individual batch of drug or vehicle was more-or lessprovocative of reactions than the others. On the other hand it is apparent from consideration of the graphs that, while the sequelæ were minimal in patients treated with 100,000 Oxford units (Figs. 7 to 10 ), these are of essentially similar character to those occurring in the higher dosage groups (Figs. 11 to 21). The distribution of cases, schemes of penicillin treatment, and incidence of uterine sequelæ are indicated in Table I.

TABLE I

PENICILLIN DOSAGE AND INCIDENCE OF UTERINE SEQUELE

\begin{tabular}{|c|c|c|c|c|c|c|c|c|c|c|c|c|c|c|c|c|c|c|c|c|c|}
\hline $\begin{array}{l}\text { Total dosage } \\
\text { of penicillin }\end{array}$ & \multicolumn{3}{|c|}{$\begin{array}{c}100,000 \\
\text { units }\end{array}$} & \multicolumn{3}{|c|}{$\begin{array}{c}150,000 \\
\text { units }\end{array}$} & \multicolumn{3}{|c|}{$\begin{array}{c}200,000 \\
\text { units }\end{array}$} & \multicolumn{3}{|c|}{$\begin{array}{c}300.000 \\
\text { units }\end{array}$} & \multicolumn{3}{|c|}{$\begin{array}{c}2,400,000 \\
\text { units }\end{array}$} & \multicolumn{3}{|c|}{$\begin{array}{c}2,400,000 \\
\text { units }\end{array}$} & \multirow{2}{*}{\multicolumn{3}{|c|}{ Total }} \\
\hline \multirow[t]{2}{*}{$\begin{array}{l}\text { Details of } \\
\text { administration } \\
\text { and salts used }\end{array}$} & \multicolumn{3}{|c|}{$\begin{array}{c}5 \times 20,000 \\
\text { units } \\
\text { 3-hourly } \\
\text { (aqueous } \\
\text { solution) } \\
\text { sodium }\end{array}$} & \multicolumn{3}{|c|}{$\begin{array}{c}5 \times 30,000 \\
\text { units } \\
\text { 3-hourly } \\
\text { (aqueous } \\
\text { solution) } \\
\text { sodium } \\
\text { and calcium }\end{array}$} & \multicolumn{3}{|c|}{$\begin{array}{l}\text { single dose } \\
\text { (emulsion) } \\
\text { calcium }\end{array}$} & \multicolumn{3}{|c|}{$\begin{array}{l}\text { single dose } \\
\text { (emulsion) } \\
\text { calcium }\end{array}$} & \multicolumn{3}{|c|}{$\begin{array}{l}\text { 40,000 units } \\
\text { 3-hourly } \\
\text { for } 7 \frac{1}{2} \text { days } \\
\text { (aqueous } \\
\text { solution) } \\
\text { sodium } \\
\text { and calcium }\end{array}$} & \multicolumn{3}{|c|}{$\begin{array}{l}\text { single dose } \\
300,000 \\
\text { units daily } \\
\text { for } 8 \text { days } \\
\text { (emulsion) } \\
\text { calcium }\end{array}$} & & & \\
\hline & 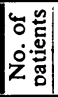 & | & o윯 & 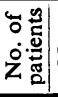 & Z密 & ○゚ & 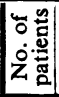 & 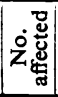 & ○胥 & 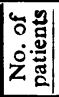 & Zi & ○芯 & 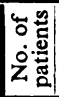 & 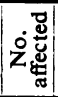 & ○䜦 & 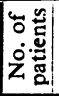 & 完莺 & ¿ & 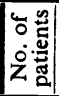 & 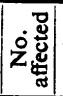 & 苞 \\
\hline Non-pregnant .. & 8 & 6 & $75 \cdot 0$ & 42 & 40 & $95 \cdot 2$ & 46 & 34 & $73 \cdot 9$ & 4 & 4 & 100 & 96 & 94 & 97.9 & 10 & 10 & 100 & 206 & 188 & 913 \\
\hline Pregnant.. & - & - & - & 6 & 1 & $16 \cdot 7$ & 6 & 1 & $16 \cdot 7$ & - & $\ldots$ & - & 20 & 12 & $60 \cdot 0$ & - & - & - & 32 & 14 & $43 \cdot 8$ \\
\hline Puerperal & - & - & $\cdots-$ & 4 & 2 & $50 \cdot 0$ & - &.- & - & - & - & - & 12 & 10 & $83 \cdot 3$ & - & - & - & 16 & 12 & $75 \cdot 0$ \\
\hline $\begin{array}{c}\text { Amenorrhœa : } \\
\text { Physiological } \\
\text { (no cause } \\
\text { ascertained) } \\
\text { Pubertal } \\
\text { Menopausal } \because\end{array}$ & $\frac{4}{-}$ & $\frac{4}{-}$ & $\frac{100}{-}$ & $\overline{-}$ & $=$ & $\bar{z}$ & $\bar{z}$ & 二 & 三 & 三 & 二 & $\bar{z}$ & $\begin{array}{l}2 \\
2 \\
2\end{array}$ & $\begin{array}{l}2 \\
2 \\
2\end{array}$ & $\begin{array}{l}100 \\
100 \\
100\end{array}$ & $\overline{-}$ & $\overline{-}$ & $\bar{z}$ & $\begin{array}{l}6 \\
2 \\
2\end{array}$ & $\begin{array}{l}6 \\
2 \\
2\end{array}$ & $\begin{array}{l}100 \\
100 \\
100\end{array}$ \\
\hline Normal controls & - & - & - & 3 & 3 & 100 & - & - & - & - & - & - & - & - & - & - . & - & - & 3 & 3 & 100 \\
\hline
\end{tabular}




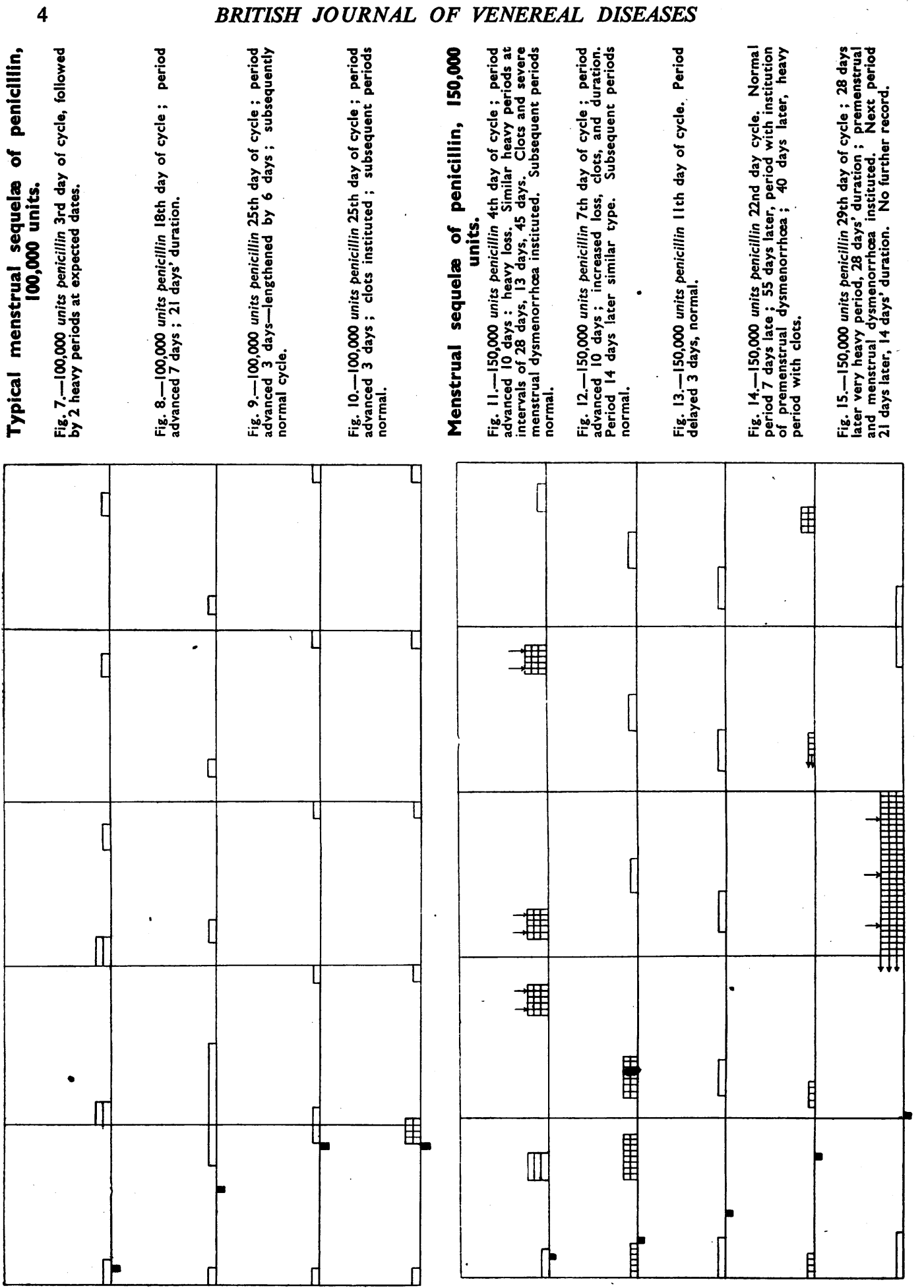




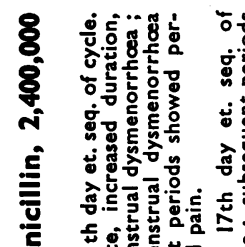

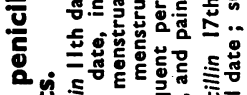

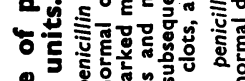

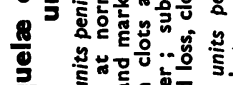

용 8

\%

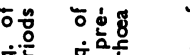
范 ธ่ 空.

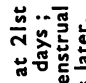
Ln

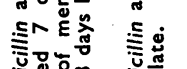

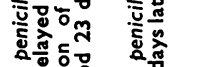

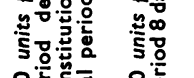

8

$8>$

$8 \%$

完

ह

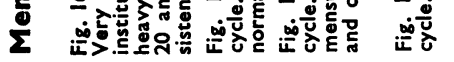

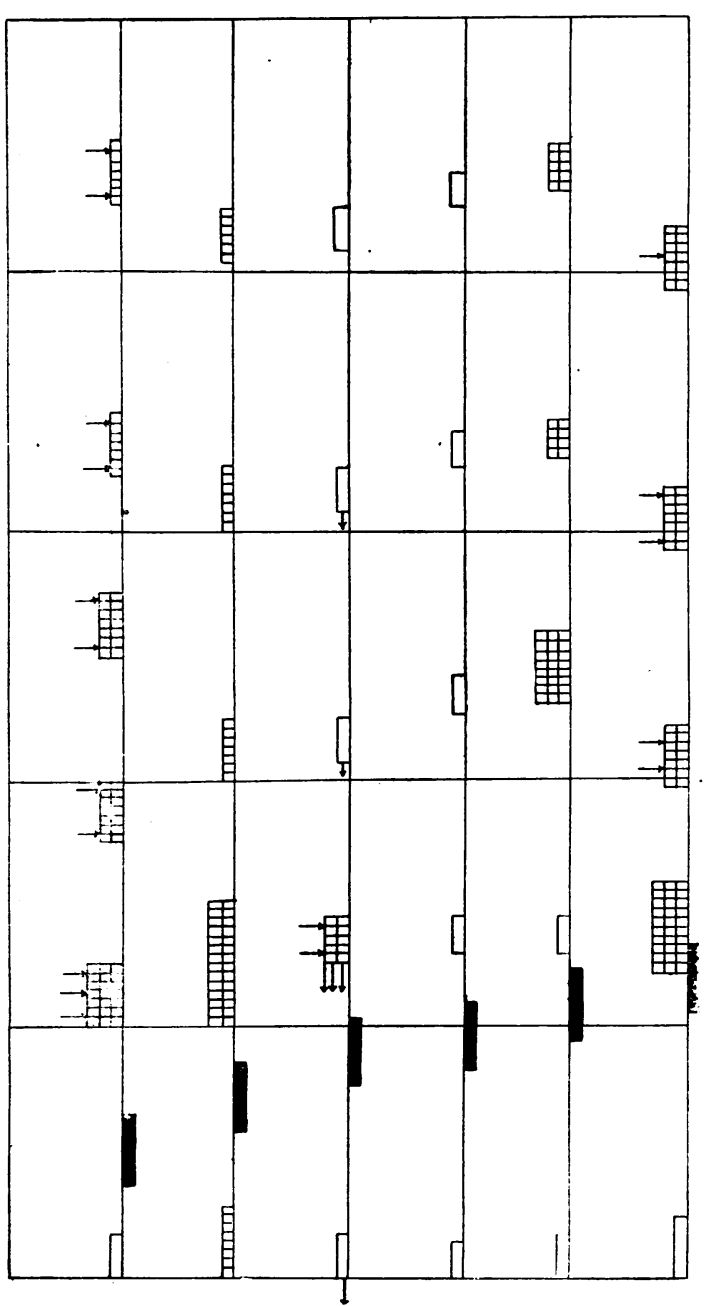

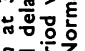

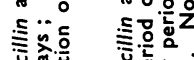

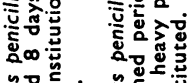

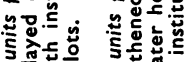

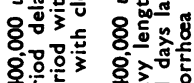

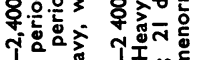

กี่

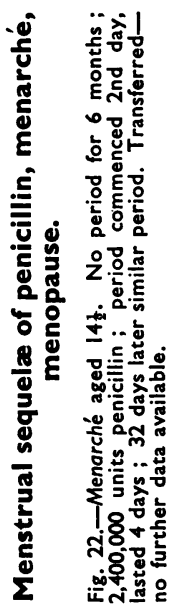

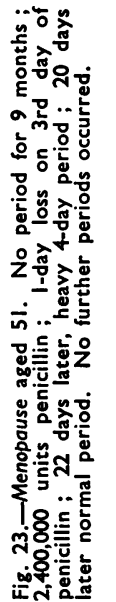

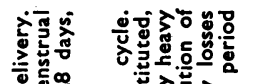

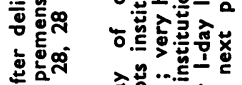

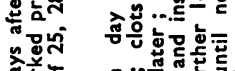

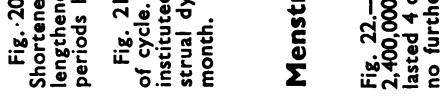

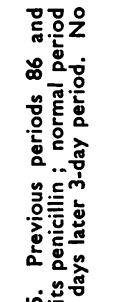

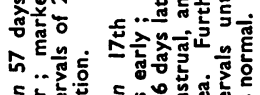

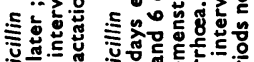
这行

幽8

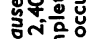

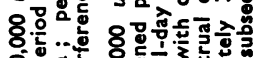

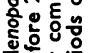

陆

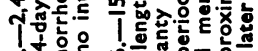

Iिए

तें

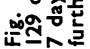

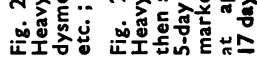

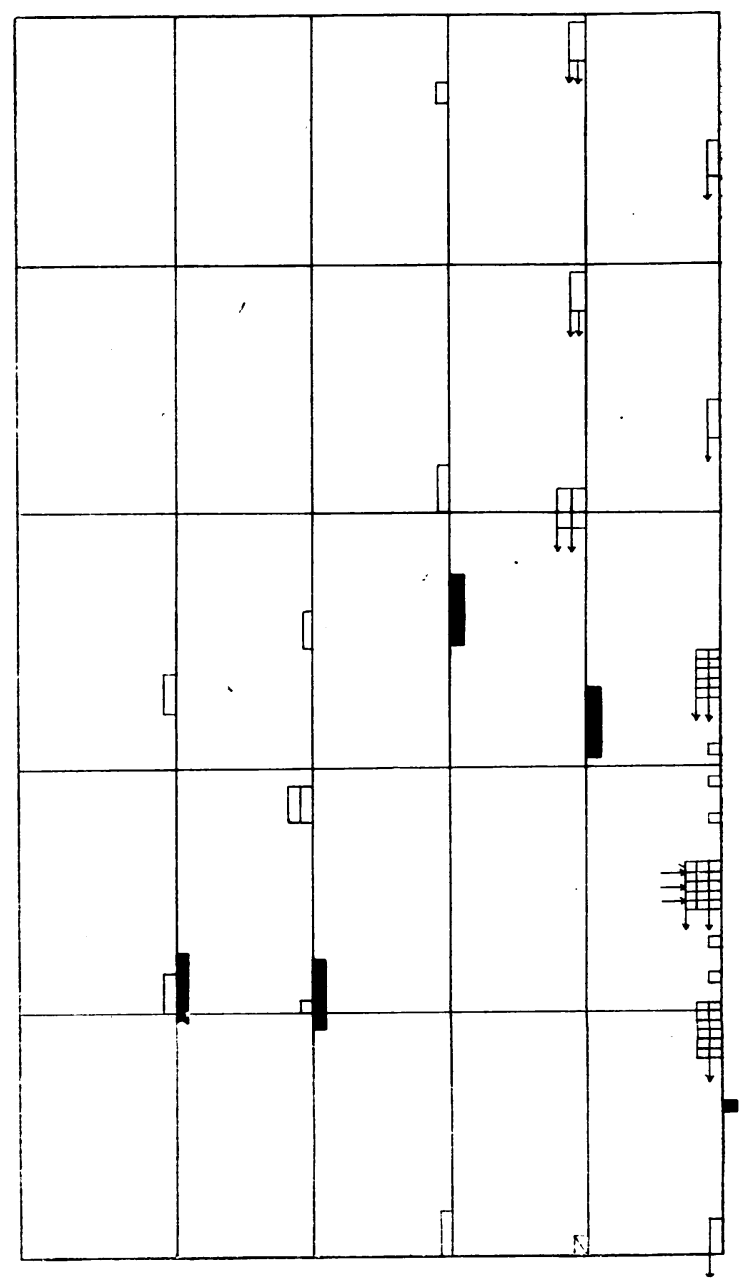


TABLE II

PENICILLIN DOSAGE AND MENSTRUAL PERIODS AFFECTED

\begin{tabular}{|c|c|c|c|c|c|c|}
\hline \multirow{2}{*}{$\begin{array}{l}\text { Penicillin : } \\
\text { dosage in } \\
\text { Oxford units }\end{array}$} & \multirow{2}{*}{$\begin{array}{c}\text { Number } \\
\text { of } \\
\text { patients }\end{array}$} & \multirow{2}{*}{$\begin{array}{l}\text { Number } \\
\text { of patients } \\
\text { affected }\end{array}$} & \multicolumn{4}{|c|}{ Post-penicillin menstrual periods affected } \\
\hline & & & 1 & 1,2 & $1,2,3$ & $1,2,3,4$ \\
\hline $\begin{array}{r}100,000 \\
150,000 \\
200,000 \\
300,000 \\
2,400,000\end{array}$ & $\begin{array}{r}8 \\
42 \\
46 \\
4 \\
106\end{array}$ & $\begin{array}{r}6 \\
40 \\
34 \\
4 \\
104\end{array}$ & $\begin{array}{r}2 \\
30 \\
20 \\
2 \\
64\end{array}$ & $\begin{array}{r}4 \\
4 \\
10 \\
2 \\
24\end{array}$ & $\begin{array}{l}\overline{4} \\
4 \\
4\end{array}$ & $\frac{\overline{2}}{\overline{12}}$ \\
\hline Total & 206 & 188 & 118 & 44 & 12 & 14 \\
\hline Percentage & 100 & $91 \cdot 3$ & $57 \cdot 3$ & $21 \cdot 4$ & $5 \cdot 8$ & $6 \cdot 8$ \\
\hline
\end{tabular}

\section{Menstrual Function Sequele}

Menstrual Periods.-Analysis of the menstrual periods affected in the various groups of patients (Table II) indicates that, in the vast majority, the sequelæ have been related to the first 2 postpenicillin cycles although in some cases the third and fourth cycles may also be affected. There is again a striking similarity in the pattern of results in the various groups independent of time-dosage factors.

The chief symptomatic changes in relation to the menstrual function are shown in Table III. Approximately $60 \%$ of the patients show changes in cycle, in duration of period, and in menstrual loss.

Menstrual Cycle.-The cycle was lengthened in $27.2 \%$ of cases, the average increase being 9 to 11 days (limits, 2 to 41 days); it was shortened in $32.7 \%$ of cases, the average being 10 to 11 days (limits, 2 to 20 dáys). In the remaining $40 \cdot 1 \%$ the cycles were unaffected.

Menstrual Flow.-The duration of menstrual flow was lengthened in $44.5 \%$ of cases, the average increase being 5 to 6 days (limits, 1 to 22 days) beyond the patient's normal; it was shortened in $11.7 \%$, the average being 2 days. The remaining $\mathbf{4 3 . 8} \%$ were unaffected.

Menstrual Loss.-This was increased in $56.1 \%$ of cases, the increase in the majority being " marked," but in $10 \%$ being extremely heavy. Loss was decreased in $2.5 \%$ of cases, while the remaining $41.4 \%$ were unaffected. The occurrence of menstrual clotting for the first time was noted by $12 \cdot 1 \%$ of patients.

Dysmenorrhoea.-Perhaps the most striking feature of penicillin therapy has been the institution of premenstrual or menstrual dysmenorrhœa in approximately one-third of the cycles, while, on the other hand, some $10 \%$ of patients normally suffering dysmenorrhœa experienced temporary or permanent relief. Premenstrual pain commonly occurred 2 days before the onset of flow, being of moderate severity in the majority of cases. Exceptionally, the associated abdominal pain and tenderness were hyperacute and were highly suggestive of an " acute abdomen." There were, however, no associated temperature, pulse rate, or respiratory increases, and the pain usually abated with the onset of menstrual flow. Menstrual pain, while usually of moderate degree in those affected, was occasionally of the utmost severity.

Mittelschmertz Phenomenon.-The mittelschmertz phenomenon was noted in 8 patients, 6 of whom had had 2,400,000 units of penicillin for the treatment of early syphilis, the remaining 2 receiving 200,000 units for the treatment of gonorrhœa. None of these patients had previously experienced this phenomenon, nor has it recurred. One other patient complained of intermenstrual bleeding ; she noted a scanty 1-day loss, recurring every third day for 2 menstrual cycles and commencing 3 days after the cessation of the first post-penicillin period (Fig. 26).

At the start of this investigation, an attempt was made to determine by graphical records whether a general pattern of results could be related to the time in the menstrual cycle at which penicillin was exhibited. It soon became apparent that the sequelæ-alterations in cycle, in loss, and in the occurrence of dysmenorrhœa, etc.-were unpredictable for any given patient. That, however, the sequelæ are of individual idiosyncratic pattern is shown in 5 of our cases by the recurrence of similar phenomena in the same patient on repeated administration of penicillin (Fig. 6). 
TABLE III -

POST-PENICILLIN MENSTRUAL SEQUELE

\begin{tabular}{|c|c|c|c|c|c|c|c|c|}
\hline & & \multicolumn{5}{|c|}{ Penicillin dosage in Oxford units } & \multirow[t]{2}{*}{ Total } & \multirow[t]{2}{*}{ Per cent. } \\
\hline & & 100,000 & 150,000 & 200,000 & 300,000 & $2 \cdot 4$ mil. & & \\
\hline \multicolumn{2}{|c|}{$\begin{array}{l}\text { No. of menstrual } \\
\text { periods involved }\end{array}$} & 12 & 60 & 64 & 6 & 182 & 324 & 100 \\
\hline $\begin{array}{l}\text { Menstrual cycle : } \\
\text { Lengthened } \\
\text { Shortened } \\
\text { Unaffected }\end{array}$ & $\begin{array}{l}. \\
\cdots \\
\cdots\end{array}$ & $\begin{array}{l}2 \\
2 \\
8\end{array}$ & $\begin{array}{l}18 \\
28 \\
14\end{array}$ & $\begin{array}{l}12 \\
22 \\
30\end{array}$ & $\begin{array}{l}0 \\
0 \\
6\end{array}$ & $\begin{array}{l}56 \\
54 \\
72\end{array}$ & $\begin{array}{r}88 \\
106 \\
130\end{array}$ & $\begin{array}{l}27 \cdot 2 \\
32 \cdot 7 \\
40 \cdot 1\end{array}$ \\
\hline $\begin{array}{l}\text { Duration of period } \\
\text { Lengthened } \\
\text { Shortened } \\
\text { Unaffected }\end{array}$ & $\begin{array}{l}d: \\
\cdots \\
\cdots \\
\cdots\end{array}$ & $\frac{6}{6}$ & $\begin{array}{r}26 \\
2 \\
32\end{array}$ & $\begin{array}{r}22 \\
2 \\
40\end{array}$ & $\frac{6}{-}$ & $\begin{array}{l}84 \\
34 \\
64\end{array}$ & $\begin{array}{r}144 \\
38 \\
142\end{array}$ & $\begin{array}{l}44 \cdot 5 \\
11 \cdot 7 \\
43 \cdot 8\end{array}$ \\
\hline $\begin{array}{l}\text { Menstrual loss : } \\
\text { Increased } \\
\text { Decreased } \\
\text { Unaffected }\end{array}$ & $\begin{array}{l}. \\
\because \\
.\end{array}$ & $\frac{10}{2}$ & $\begin{array}{r}46 \\
4 \\
10\end{array}$ & $\frac{30}{34}$ & $\frac{4}{2}$ & $\begin{array}{r}92 \\
4 \\
86\end{array}$ & $\begin{array}{r}182 \\
8 \\
134\end{array}$ & $\begin{array}{r}56 \cdot 1 \\
2 \cdot 5 \\
41 \cdot 4\end{array}$ \\
\hline $\begin{array}{l}\text { Clots : } \\
\text { Increased } \\
\text { Decreased } \\
\text { Instituted } \\
\text { Abolished } \\
\text { Unaffected }\end{array}$ & $\begin{array}{l}. \\
\cdots \\
\cdots \\
\cdots\end{array}$ & $\begin{array}{l}\bar{z} \\
\overline{12}\end{array}$ & $\begin{array}{r}12 \\
2 \\
12 \\
34\end{array}$ & $\begin{array}{r}2 \\
6 \\
2 \\
54\end{array}$ & $\frac{\bar{z}}{\frac{\bar{x}}{6}}$ & $\begin{array}{r}6 \\
4 \\
22 \\
150\end{array}$ & $\begin{array}{r}20 \\
6 \\
40 \\
2 \\
256\end{array}$ & $\begin{array}{r}6 \cdot 1 \\
1.9 \\
12 \cdot 4 \\
0 \cdot 6 \\
79 \cdot 0\end{array}$ \\
\hline $\begin{array}{c}\text { Dysmenorrhcea } \\
\text { Premenstrual } \\
\text { Increased } \\
\text { Decreased } \\
\text { Instituted } \\
\text { Abolished } \\
\text { Unaffected } \\
\text { Menstrual } \\
\text { Increased } \\
\text { Decreased } \\
\text { Instituted } \\
\text { Abolished } \\
\text { Unaffected }\end{array}$ & $\begin{array}{l}\ldots \\
\because \\
\because \\
\cdots \\
. \\
\cdots \\
\cdots \\
\cdots\end{array}$ & $\begin{array}{l}\bar{z} \\
\overline{\overline{1}} \\
\bar{z} \\
\overline{-} \\
\overline{12}\end{array}$ & $\begin{array}{r}6 \\
2 \\
6 \\
2 \\
44 \\
\\
6 \\
2 \\
20 \\
4 \\
28\end{array}$ & $\begin{array}{l}\overline{-} \\
4 \\
2 \\
58 \\
\overline{-} \\
\overline{6} \\
\overline{58}\end{array}$ & $\begin{array}{c}\frac{2}{-} \\
\overline{2} \\
\frac{-}{4} \\
\frac{4}{2}\end{array}$ & $\begin{array}{r}6 \\
20 \\
12 \\
144 \\
- \\
2 \\
36 \\
8 \\
136\end{array}$ & $\begin{array}{r}14 \\
2 \\
30 \\
18 \\
260 \\
\\
6 \\
4 \\
66 \\
12 \\
236\end{array}$ & $\begin{array}{r}4 \cdot 3 \\
0 \cdot 6 \\
9 \cdot 3 \\
5.5 \\
80 \cdot 3 \\
1 \cdot 9 \\
1 \cdot 2 \\
20 \cdot 4 \\
3 \cdot 6 \\
72.9\end{array}$ \\
\hline
\end{tabular}

\section{Physiological Amenorrhat}

In 3 cases of physiological amenorrhœa, varying in duration from 8 to 15 weeks and for which no cause could be determined, 100,000 units of penicillin (for gonorrhœa) restored normal menstrual function. In the fourth case (of 3 months' duration) a heavy period occurred 1 week after 100,000 units of penicillin; some 30 days later 640,000 units of penicillin were administered in 2 days for a relapse manifested by arthritis; this treatment was again followed by one heavy period, and subsequently by normal cycles (Figs. 4,5 ). In the other 2 cases of approximately similar durations, courses of $2,400,000$ units for sero-negative primary and sero-positive syphilis were followed by the same result. In 2 cases of pubertal amenorrhœa of 4 and 6 months' duration respectively, occurring in patients of 14 and $14 \frac{1}{2}$ years of age who were the subjects of congenital and acquired syphilis and who were treated with $2,400,000$ units of penicillin, menstruation was re-established for 2 complete menstrual cycles : further follow up of these cases proved impracticable because of their transfer elsewhere (Fig. 22).

\section{MenOPAUSE}

In 2 patients at the menopause, penicillin temporarily restored the menstrual function. In 1 patient, aged 51, in whom no menstrual loss had been noted for 9 months, a 1-day flow occurred 
on the third day of a $7 \frac{1}{2}$-day $(2,400,000$ unit) course of penicillin. This was followed 22 days later by a 4-day period of moderately heavy loss. No further menstruation was noted. The other patient, aged 45 , had been increasingly irregular for about a year, the last menstrual losses being 86 and 129 days respectively before the commencement of a $2,400,000$ unit course of penicillin for late syphilis. Seven days after completion of penicillin therapy a normal 6-day menstrual loss was experienced. This was followed by a 3-day loss $\mathbf{4 0}$ days later, since when the menses have ceased completely (Figs. 23 and 24).

\section{Pregnancy}

Of 32 cases of pregnancy treated with penicillin (Table IV), 12 experienced uterine cramps. Of this number 3 showed, in addition, uterine hæmorrhage. Cramps occurred most commonly on the first day, usually after the second or third injection of penicillin, and consisted of a series of 1 to 3 moderately vigorous uterine contractions, followed by a sequence variable in number and gradually decreasing in amplitude. The contractions lasted over a period varying from a few minutes up to 2 to 3 hours. Recurrence of the pains was unusual. Bleeding was in no case of serious import, and varied from a slight staining of the linen to marked soiling of a sanitary pad.

Labour occurred in 5 patients, 3 between the seventh and ninth months of gestation, and the remaining 2 at "term." In the 3 patients of the first group (seventh to ninth month) labour pains followed "penicillin cramps" without any initial hæmorrhage. In 1 patient ( 7 months pregnant, in whom asymptomatic early syphilis was detected by routine ante-natal serological tests) the uterine cramps, of very moderate severity, began on the first day of penicillin treatment, passed off in $1 \frac{1}{2}$ hours, and were followed after an interval of

TABLE IV

PENICILLIN DOSAGE AND INCIDENCE OF UTERINE SEQUELA IN PREGNANCY

\begin{tabular}{|c|c|c|c|c|c|c|c|c|c|}
\hline \multirow{3}{*}{$\begin{array}{l}\text { Month } \\
\text { of preg- } \\
\text { nancy }\end{array}$} & \multirow{3}{*}{$\begin{array}{c}\text { Dosage of } \\
\text { penicillin } \\
\text { (Oxford } \\
\text { units) }\end{array}$} & \multirow{3}{*}{$\begin{array}{c}\text { Number } \\
\text { of } \\
\text { patients }\end{array}$} & \multicolumn{7}{|c|}{ Uterine sequelæ } \\
\hline & & & \multicolumn{2}{|c|}{ Uterine cramps } & \multicolumn{2}{|c|}{ Bleeding * } & \multicolumn{2}{|c|}{ Labour } & \multirow{2}{*}{$\begin{array}{l}\text { Day of onset of } \\
\text { sequelæ (from } \\
\text { commencement } \\
\text { of injections) }\end{array}$} \\
\hline & & & $\begin{array}{l}\text { No. of } \\
\text { patients } \\
\text { affected }\end{array}$ & $\begin{array}{c}\% \\
\text { affected }\end{array}$ & $\begin{array}{l}\text { No. of } \\
\text { patients } \\
\text { affected }\end{array}$ & $\stackrel{\%}{\%}$ affected & $\begin{array}{l}\text { No. of } \\
\text { patients } \\
\text { affected }\end{array}$ & $\begin{array}{c}\% \\
\text { affected }\end{array}$ & \\
\hline \multirow{3}{*}{$0-3$} & 150,000 & 2 & 1 & 50 & 1 & 50 & - & - & 5 \\
\hline & 200,000 & 2 & - & - & - & - & - & - & - \\
\hline & $2,400,000$ & 2 & - & - & - & - & - & 一 & - \\
\hline \multirow{3}{*}{$4-6$} & 150,000 & - & - & - & - & - & - & - & - \\
\hline & 200,000 & 4 & - & 一 & - & - & - & - & - \\
\hline & $2,400,000$ & 6 & 2 & $33 \cdot 3$ & 1 & $16 \cdot 7$ & 一 & - & 1,4 \\
\hline \multirow{3}{*}{ 7-9 } & 150,000 & 4 & 1 & 25 & 1 & 25 & - & 一 & - \\
\hline & 200,000 & - & - & - & - & - & - & - & - \\
\hline & $2,400,000$ & 10 & 7 & 70 & 1 & 10 & 3 & 30 & $1,1,2,3,4,6,8$ \\
\hline \multirow{4}{*}{ Term $\dagger$} & 150,000 & - & - & - & - & - & - & - & - \\
\hline & 200,000 & - & - & - & - & - & - & - & - \\
\hline & $2,400,000$ & 2 & 2 & 100 & - & - & 2 & 100 & 1,8 \\
\hline & & 32 & 13 & $40 \cdot 6$ & 4 & $12 \cdot 5$ & 5 & $15 \cdot 6$ & - \\
\hline
\end{tabular}

* Bleeding was associated with uterine cramps and these cases are included in this group. + Patients whose treatment began within 24 hours of the calculated date of confinement. 
4 hours by labour pains. A macerated fotus was expelled some 10 hours later. In this case for 4 or 5 days before the onset of labour fotal movements had not been felt nor the fotal heart sounds detected, and the appearance of the fœetus was consistent with death at that time.

The second patient was suffering from late congenital syphilis, also detected by ante-natal serological tests. Uterine cramps of moderate severity began 2 hours after completion of the $7 \frac{1}{2}$ days' course of treatment and persisted for 8 to 10 hours. Labour, which began the following day, resulted in a healthy 7 months' infant.

In the third patient, 8 months pregnant and the subject of untreated late secondary syphilis, fœtal movements ceased on the third day of penicillin treatment and the fœtal heart sounds could no longer be heard. Uterine cramps occurred on the third and fourth days but were of very mild character. Apart from this, the course of penicillin was completed uneventfully. Thirty-six hours later labour commenced and resulted in the birth of a small macerated fotus.

The role of penicillin in causing labour must be regarded as doubtful in the first and third cases, because of the fotal death due to syphilis, but it cannot be ignored as a probable precipitant of labour in the second case. In the 2 cases at " term" i.e. within 48 hours of calculated date, labour commenced in 1 following uterine cramps consequent on the second penicillin injection, and in the other following cramps occurring on the last day of the course of treatment. From these cases at term no conclusions can be drawn. It seems, however, permissible to suggest that the sequelæ of pepicillin treatment in pregnancy are more likely to occur with the higher dosages and in the more advanced stages of pregnancy.

\section{Puerperium}

Of 16 patients whose penicillin treatment began early in the puerperium, 12 showed some alteration in the lochia. Four patients were treated with 150,000 units. Of these, 2 , treated on the fifth and eleventh days respectively, were unaffected ; 1 (fourth day), showed a marked-increase in lochia rubra, persisting for 36 hours, which then rapidly diminished and became serous; 1 (eleventh day) showed a rapid diminution in lochia alba which had completely ceased at the termination of the 12-hours' penicillin administration. No further visible loss was reported.

Twelve patients were treated with $2,400,000$ units. Two were completely unaffected. Three, after penicillin commencing on the fourth, fifth, and eighth days of the puerperium respectively, showed a marked increase in loss, temporary in nature, and in no case persisting after the termination of the penicillin course or altering the normal sequence of lochial changes. Six (third, fourth, fourth, sixth, seventh, and tenth days respectively) experienced marked decrease of lochial flow without alteration of the total duration. In 1 patient (sixth day) however, the lochia ceased completely within 12 hours of the commencement of the penicillin course and did not become re-established.

\section{LACTATION}

During the puerperium it was noted that changes in lactation occurred in relation to penicillin therapy. Of the 4 patients treated with 150,000 units, 2 were unaffected, 1 showed a temporary decrease of secretion for $\mathbf{4 8}$ hours after penicillin administration, while 1 , after a progressive diminution in secretion, became "dry" after 5 days in spite of all efforts to restore the function. Of the 12 patients treated with $2,400,000$ units, 2 showed no lactatory changes, and 8 experienced a temporary decrease limited to the duration of penicillin administration. In 2 cases, however, lactation completely ceased and could not be re-established. Two of the 3 patients exhibiting failure of lactation had, in previous pregnancies, successfully breast-fed their infants.

The vagary of lochial alterations does not appear to depend upon the dosage or point in the puerperium at which the penicillin therapy was commenced. Similarly the stage of disease had no bearing; the 4 cases of gonorrhœa $(150,000$ units) were all uncomplicated, while analysis of the syphilis group shows no significant variations in sequelæ in the early, late, and late congenital stages. The numbers of cases observed are, however, so small that only the most tentative conclusions can be drawn.

In regard to lactation, however, a more constant sequel is seen in the depression of the function in 75 per cent. of the patients observed, the criterion of " decrease" being the necessity for the institution of supplementary feeding. Of those affected, 25 per cent. permanently ceased to lactate. Apart from the penicillin no extraneous factors could be elicited, and it seems not unreasonable to conclude that the drug was the inhibiting agent. No constant relationship was noted between the occurrence or type of lochial sequelæ and the diminution of lactation. 
Our observations on patients treated later in the puerperium or during the normal lactation period are few, numbering only 3 cases, and are not included in Table $I$. In 1 case a course of $2,400,000$ units, begun on the twenty-fourth day after delivery for late asymptomatic syphilis, resulted in a marked decrease of lactation during the $7 \frac{1}{2}$ days of treatment, and supplementary feeding had to be instituted. This measure became unnecessary within 48 hours of the termination of penicillin injections. In a second case of late congenital syphilis, treated from the twenty-eighth day as an out patient with daily injections of penicillin in oil-wax emulsion, no lactatory changes were reported. One-day menstrual losses, however, occurred on the thirty-third, forty-first, and fortyeighth days; no local cause could be detected, and no further losses were reported. In the third patient (late syphilis, 2,400,000 units in oil-wax emulsion) treatment was begun at the fifty-seventh day; no lactatory changes were reported, but a normal-duration heavy menstrual period with marked, unaccustomed premenstrual pain occurred 17 days after completion of drug therapy ; in this case menstruation continued at normal intervals without change in lactation (Fig. 25).

\section{Summary and Conclusions}

Menstrual cycle sequelæ were found to occur in 91.3 per cent. of 206 non-pregnant female patients treated with penicillin in varying time-dosage schedules. The principal changes noted were alteration (lengthening or shortening) of the cycle and duration of flow, and the institution of premenstrual or menstrual dysmenorrhœa, occasionally of the utmost severity.

Uterine bleeding and/or cramps occurred in 43.8 per cent. of 32 women at varying stages of pregnancy who were undergoing penicillin therapy; in 1 of these cases it is probable that this form of treatment precipitated the onset of labour at the seventh month.

Alterations in the lochia were observed in
75 per cent. of 16 women treated during the first fortnight of the puerperium ; increased loss during the period of drug-therapy was seen in 4 , decrease in 7 , and complete ablation in 1.

Lactation was diminished in 75 per cent. of 16 cases. While this decrease was usually limited to the injection period and normal function was subsequently rapidly regained, permanent cessation of lactation occurred in 25 per cent. of those affected.

Restoration of normal menstrual function was noted in 1 patient treated late in the puerperium, a normal cycle becoming established without interference with lactation.

Reactions to penicillin cannot be forecast. They appear to result from individual idiosyncracy, as is evidenced by the recurrence of a similar pattern of sequelæ on re-exhibition of the drug.

It is believed that these phenomena are caused by the penicillin available to us or to the impurities inseparable from the process of manufacture. That the latter hypothesis is the case is suggested by the decreasing frequency in recent months of such reactions, despite greatly increased penicillin dosage, and by the absence of sequalæ in 2 patients treated with pure penicillin.

We desire to express our thanks to the nursing staff of $Q$ Ward, Southmead Hospital, whose co-operation has made the collection of data easier, and to the Medical Officer of Health of Bristol for permission to publish these observations.

\section{REFERENCES}

Leavitt, H. M. (1945). J. vener. Dis. Inf., 26, 150. Lentz, J. W., Ingraham, N. R., Beerman, H., and Stokes, J. H. (1944). J. Amer. med. Ass., 126, 408.

Mascall, W. N. (1945). Brit.J. vener. Dis., 21, 157. Speiser, D. M., and Thomas, E. W. (1946). J. vener. Dis. Inf., 27, 20.

Walker; B. (1945). 'Brit. J. vener. Dis., 21, 157. 